\title{
Alteration of Tight and Adherens Junctions on 50-Hz Magnetic Field Exposure in Madin Darby Canine Kidney (MDCK) Cells
}

\author{
Zoltán Somosy ${ }^{1, *}$, Zsolt Forgács ${ }^{2}$, Gabriella Bognár ${ }^{1}$, Katalin Horváth ${ }^{2}$, \\ and Gyöző Horváth ${ }^{3}$ \\ 1"Fodor József" National Center of Public Health, "Frédéric Joliot-Curie" National \\ Research Institute for Radiobiology and Radiohygiene, Budapest, Hungary; "Fodor \\ József" National Center of Public Health, National Institute of Chemical Safety, Budapest, \\ Hungary; ${ }^{3}$ Institute of Health Protection, Hungarian Defence Forces, Budapest, Hungary \\ E-mail: somosy@hp.osski.hu; forgacs@freemail.hu; iribisz@freemail.hu; bognár@osski.hu; hgyozo@osski.hu
} Received 7/9/2004; Revised 8/23/2004; Accepted 8/23/2004; Published October 20, 2004

Adherens (AJ) and tight junctions (TJ), as integrated parts of the junctional complex, are multifunctional specialized regions of the cell membrane in epithelial cells. They are responsible for cell-to-cell interactions and also have great importance in cellular signaling processes including Wnt protein-mediated signals. As electromagnetic field (EMF) exposure is known to cause alterations in the function as well as supramolecular organization of different cell contacts, our goal was to investigate the effect of $50-\mathrm{Hz}$ magnetic field (MF) exposures on the subcellular distribution of some representative structural proteins (occludin, ß-catenin, and cadherin) found in AJ and TJ. Additionally, cellular ß-catenin content was also quantified by Western blot analysis.

$50-\mathrm{Hz}$ MF exposures seemed to increase the staining intensity (amount) of occludin, cadherins, and ß-catenin in the junctional area of MDCK cells, while Western blot data indicated the quantity of $\beta$-catenin was found significantly decreased at both time points after EM exposures.

Our results demonstrate that MF are able to modify the distribution of $\mathrm{TJ}$ and AJ structural proteins, tending to stabilize these cell contacts. The quantitative changes of ß-catenin suggest a causative relationship between MF effects on the cell junctional complex and the Wnt signaling pathway.

KEYWORDS: adherens junction, tight junction, magnetic field, occludin, cadherin, $\beta$-catenin, Wnt signal, immunohistochemistry

DOMAINS: microscopy, cell and tissue culture, signaling, biophysics

\section{INTRODUCTION}

Cell contacts are multifunctional specialized regions of the cell membrane. They are responsible for establishing cell-to-cell and cell-to-matrix physical contacts and also play critical roles in epithelial 
barrier functions, intercellular communication mechanisms, as well as biological processes that are involved in or related to cell signaling[1,2,3,4]. Tight (TJ) and adherens junctions (AJ) are stable and sophisticated molecular complexes establishing multifunctional connections between the junctional complexes of epithelial cells. These cell couplings physically stabilize the neighboring cells, regulate the paracellular transports of ions and other matters, inhibit the lateral shift of membrane proteins, and their signal transmitter and signal generating function is also known[1,2,3,4,5]. The respective coupling proteins in $\mathrm{TJ}$ and $\mathrm{AJ}$ are the claudins, occludin, and cadherins, while in $\mathrm{AJ} \mathrm{ZO}$ proteins and catenins are the linkers to the cytoskeleton[1,2,3,4,5]. Recently, it has been recognized that ZO-1 protein is a common structural protein for both $\mathrm{TJ}$ and $\mathrm{AJ}$ as $\mathrm{ZO}-1$ is able to bind to many proteins, including $\mathrm{ZO}-2$ and $\mathrm{ZO}-3$, occludin, claudins, ZO-1-associated nucleic acid-binding protein, and $\alpha$-catenin[[6,7]. This ZO-1mediated connection is the structural basis of the cooperation between AJ and TJ.

Beyond its structural role in AJ, B-catenin also has an important second function, i.e., in its unbound free form it can act as a transcriptional cofactor when stimulated by the Wnt signal transduction pathway[2,4,5,8,9,10,11]. This signaling pathway is involved in a variety of cellular processes including cell proliferation, differentiation, embryogenesis, and oncogenesis. In this process, cells can transmit information from the cell surface to the nucleus. In Wnt signaling, the presence and amount of B-catenin is regulated by the ratio of its free and bound forms, and also by the amount of the free protein in the cytoplasmic pool[8,9,10,11].

Biological membranes, including cell membrane, are playing an essential role in the cellular responses to electric and electromagnetic field (EMF) exposures[12,13,14]. However, the mechanism(s) standing behind the biophysical interactions at the cell membrane are still not exactly understood. It is generally accepted that the initial biochemical or metabolic state of the cell membrane, as well as the functional and supramolecular organization of its specific regions (receptors, cell contact areas), are sensitive targets of electric and EMF exposures[15,16,17,18,19]. Following EMF exposures, structural and functional changes are detectable in various types of cell contact sites[20,21,22,23,24,25,26,27]. There are available data describing how gap junction-mediated intercellular chemical communications are modified by EMF exposures[20,21]. The EMF-induced expression and/or redistribution of certain integrins and other adhesion molecules can modify cell-to-cell and cell-to-extracellular matrix (ECM) contacts[22,23,24,25,26,27].

Nowadays, studies on the TJ- and AJ-mediated blood-brain barrier alterations following microwave and MF exposures are favored areas of nonionizing cellular radiobiology. By now it has become evident that this barrier is highly sensitive to the heat generated by microwaves in the exposed biological target. On the other hand, there are some conflicting data regarding the involvement of the nonthermal effects of microwave and MF exposures in these processes[28,29,30]. As AJ and TJ are involved in the regulation of this permeability barrier, it is important to know whether the function, biochemical characteristics, localization, and quantity of their structural proteins are altered on nonionizing field exposure. Though the nonionizing radiation-induced redistribution of junctional proteins is known from the literature, this effect has not been investigated so far on in vitro cellular model systems generally used for junctional complex studies.

Therefore, in this work, the effect of $50-\mathrm{Hz}$ EMF exposure was studied on the localization characteristics of occludin, cadherins, and $\beta$-catenin in such a cellular model, i.e., Madin-Darby canine kidney (MDCK) cells by immunohistochemistry. These investigations inform about the MF-induced structural changes of the junctional strands, as well as about the relationship between the quantity and staining characteristics of junctional proteins. Taking into account that the so-called transcriptional cofactor function of $\beta$-catenin highly depends on its total cellular concentration, Western blotting for this protein was also included in our methodology. 


\section{MATERIALS AND METHODS}

\section{Cell Culture}

Madin-Darby canine kidney cells (MDCK cells) were plated in 24-well polystyrene culture plates on glass coverslips and maintained in Dulbecco's Modified Eagle's Medium (containing 10\% fetal calf serum, $4 \mathrm{mM}$ L-glutamine, 10 units $/ \mathrm{ml}$ penicillin, and $10 \mathrm{mg} / \mathrm{ml}$ streptomycin) at $37^{\circ} \mathrm{C}$ in a $5 \% \mathrm{CO}_{2}$ moist atmosphere. For studies, confluent cultures of MDCK cells were used.

\section{AC MF Exposures}

Cell cultures were exposed in a $\mathrm{CO}_{2}$ incubator at $37^{\circ} \mathrm{C}$ to $\mathrm{AC} \mathrm{MF}$ vertically parallel to the cylinder axis of a cylindrical recording chamber. The frequency of the field was $50 \mathrm{~Hz}$; the flux density B (AC) was 500 $\mu \mathrm{T}$ (root mean square). Two coils in the Helmholtz arrangement were used to produce the vertical AC MF. Coils were manufactured from 0.3-mm copper wire with an inner diameter of $12 \mathrm{~cm}$ and using 85 turns for each coil. They were connected collaterally (as a pair) with the resultant resistance of 4.2 ohms. The MF was measured by a three-dimensional MF meter (Fluxset 3C), i.e., a one-dimensional Hall-probe connected to a gaussmeter (EFA-3) MF measurement system. The spectral component of the applied and background MF was also analyzed. In the test laboratory, Earth's MF was $46 \mu \mathrm{T}$. The background 50-Hz MF in the incubator was 40/300 nT (heating off/on). The stray field of the applied 50-Hz MF at the place of the unexposed control was $1-4 \mu \mathrm{T}$, whereas the first $(100 \mathrm{~Hz})$ and second $(150 \mathrm{~Hz})$ harmonics were less than 8 and 3\%, respectively. The AC MF was generated by a power audio complex generator. Cells were fixed for immunocytochemistry after 4 and $24 \mathrm{~h}$ of exposure to the MF.

\section{Immunohistochemistry}

For the immunohistochemical detection of occludin, cadherins, and $\beta$ catenin, cells were fixed and permeabilized with methanol at $-20^{\circ} \mathrm{C}$ for at least $2 \mathrm{~h}, 4-24 \mathrm{~h}$ after MF exposures. The monoclonal antipancadherin (Clone $\mathrm{CH}-19$ ) and monoclonal anti- $\beta$-catenin (Clone 15B8) obtained from Sigma Company (St. Louis, MO, USA) were used in respective dilutions of 1:300 and 1:1000 at room temperature for $1 \mathrm{hr}$. For the detection of occludin, antioccludin antibody (Clone no. OC-3F10) obtained from Zymed Laboratories (San Francisco, CA, USA) was used in a 1:300 dilution at room temperature. The FITC-labeled antimouse secondary antibody (developed in rabbits) was obtained from Sigma Company. Cells were then mounted in Vectashield mounting medium (Vector Lab. Inst. Burgilame, CA, USA) and investigated in Axioskope (Zeiss, Germany) fluorescent microscope. Pictures were taken on color slides (Fujichrome Sensia, ISO 100) and scanned in by a slide scanner (Minolta Dimage Scan Elite II ) using 2820 dpi optical resolution, and printed by a Hewlett Packard DeskJet 990C printer.

\section{Protein Isolation and Western Blotting}

Western blotting technique was used to detect and measure the relative amount of $\beta$-catenin expressed in the control and MF-exposed (500 $\mu \mathrm{T}, 4$ and $24 \mathrm{~h}$ ) MDCK cells.

Cell monolayers from TC 80 flasks were washed twice with PBS and then rubbed off in 2-ml PBS with rubber police. Cell suspensions were centrifuged at $1500 \mathrm{~g}$ for $8 \mathrm{~min}$. After removing the supernatant, the residue was lysed in TRIS-EDTA buffer (0.02 $M$ Tris, $0.001 M$ EDTA) containing $1 \%$ dithiotreitol (1 $M$ DTT) and $0.1 \%$ phenylmethylsulfonyl fluoride $(0.1 \mathrm{M}$ PMSF). Aliquots of the cell lysates were used for the evaluation of the protein content by Bradford assay. Protein samples ( $20 \mu \mathrm{g}$ of total protein/lane) 
were separated by electrophoresis for $45 \mathrm{~min}$ at $200 \mathrm{~V}$ using $7 \%$ sodium dodecyl sulphate polyacrylamide gel electrophoresis (SDS-PAGE) gels.

Protein samples were transferred to polyvinyldiene difluoride (PVDF) membranes (Hybond-P, Amersham, England) by electroblotting at $4{ }^{\circ} \mathrm{C}$ for $2 \mathrm{~h}$ at $100 \mathrm{~V}$. In case of repeated use, membranes were stripped in Tris- $\mathrm{HCl}$ buffer containing $2 \% \mathrm{SDS}$ and $0.1 \mathrm{M} \beta$-mercaptoethanol for $30 \mathrm{~min}$ at $50^{\circ} \mathrm{C}$, and then stored at $-20^{\circ} \mathrm{C}$ until use. Membranes were placed in polyethylene bags and blocked for $1 \mathrm{~h}$ at room temperature in 5\% fat-free milk diluted in Tris-buffered saline (TBS: $10 \mathrm{mM}$ Tris- $\mathrm{HCl}$ and $150 \mathrm{mM} \mathrm{NaCl}$ $\mathrm{pH}: 7,4)$ and containing $0.1 \%$ TritonX-100 and stored at $-20^{\circ} \mathrm{C}$ until use. The blots were washed in TBS-T ( $0.1 \%$ TritonX-100 diluted in TBS). The washing buffer was replaced with the monoclonal (mouse) primary antibody diluted 1:500 in TBS-T buffer. The blots were incubated at room temperature for $2 \mathrm{~h}$ or, in the case of stripped membranes, overnight with the $\beta$-catenin (SIGMA, St. Louis, MO, USA) and pancadherin antibodies (SIGMA, St. Louis, MO, USA). The blots were then washed in TBS-T and incubated in horseradish peroxidase-linked antimouse IgG (Amersham, Oakville, ON, Canada) as a secondary antibody diluted 1:2500 in TBS-T for $1.5 \mathrm{~h}$ at room temperature. After repeated washing in TBS-T, antibody-antigen complexes in all membranes were detected by chemiluminescence (ECL kit, Amersham Life Science, Oakville, ON, Canada) and exposed to photographic film (FORTEPAN 200, Hungary) for $30 \mathrm{~min}$. The Adobe PhotoDeluxe 1.0 (Adobe Systems, Inc.) was used to scan the protein bands and these were quantified using the $1 \mathrm{D}$ image analysis software (Version 3.5).

\section{RESULTS}

Cultured MDCK cells are polarized and have a well-developed junctional complex consisting of TJ and AJ[31]. In control cells, the occludin (Fig. 1A), pan-cadherin (Fig. 1E), and $\beta$-catenin staining (Fig. 1C) distribute mainly along the borders of the cell membrane appearing as a more-or-less continuous line and show characteristic honeycomb-like pattern at the zone of the junctional complex. Accumulation of cadherins and $\beta$-catenin is also observable at the basal region of the cells (Figs. $1 \mathrm{C}$ and $1 \mathrm{E}$ ) while a faint diffuse staining pattern is characteristic to the cytoplasm. Rounded (probably mitotic) cells with intensive staining in their apical region also appear in the cultures (Figs. 1C-E).

This characteristic staining pattern of the cells and cell contact regions was not altered by the MF neither 4 nor $24 \mathrm{~h}$ after the exposure. However, the overall staining intensity of both antibodies significantly increased in the cell contact areas (Fig. 1B, D, F).

According to our Western blot data, the quantity of $\beta$-catenin was found significantly decreased at both time points after MF exposures (Fig. 2).

\section{DISCUSSION}

Our presented results indicate that MF exposure increased the staining intensity of all investigated junctional proteins (occludin, cadherin, and $\beta$-catenin) at the cell border region, i.e., at the junctional areas of MDCK cells. It is known and generally accepted in the literature that in epithelial and endothelial cells, including MDCK cells, a good correlation exist between the staining intensity, pattern, and the actual organization and amount of junctional proteins of TJ and AJ. Different physical and chemical agents, toxic metal exposure, ionizing irradiation, for example, lead to the disorganization or fragmentation as well as destabilization of tight junctional strands, and also resulted in the decreased staining of occludin and other structural proteins of TJ (ZO-1)[32,33,34,35,36,37,38,39]. On the other hand, from the accumulation of the structural proteins (indicated by the increased staining intensity) in the region of the junctional complex, one can conclude the stabilization of cell contacts. Based on our results, MF exposures are supposed to strengthen or stabilize the structural integrity of TJ and AJ. These results are entirely coherent with our earlier data obtained by microwave exposures. Carrying out detailed morphometric analysis on tight junctional strands after microwave in vivo exposure of mouse jejunal cells on freeze-fractured replicas 

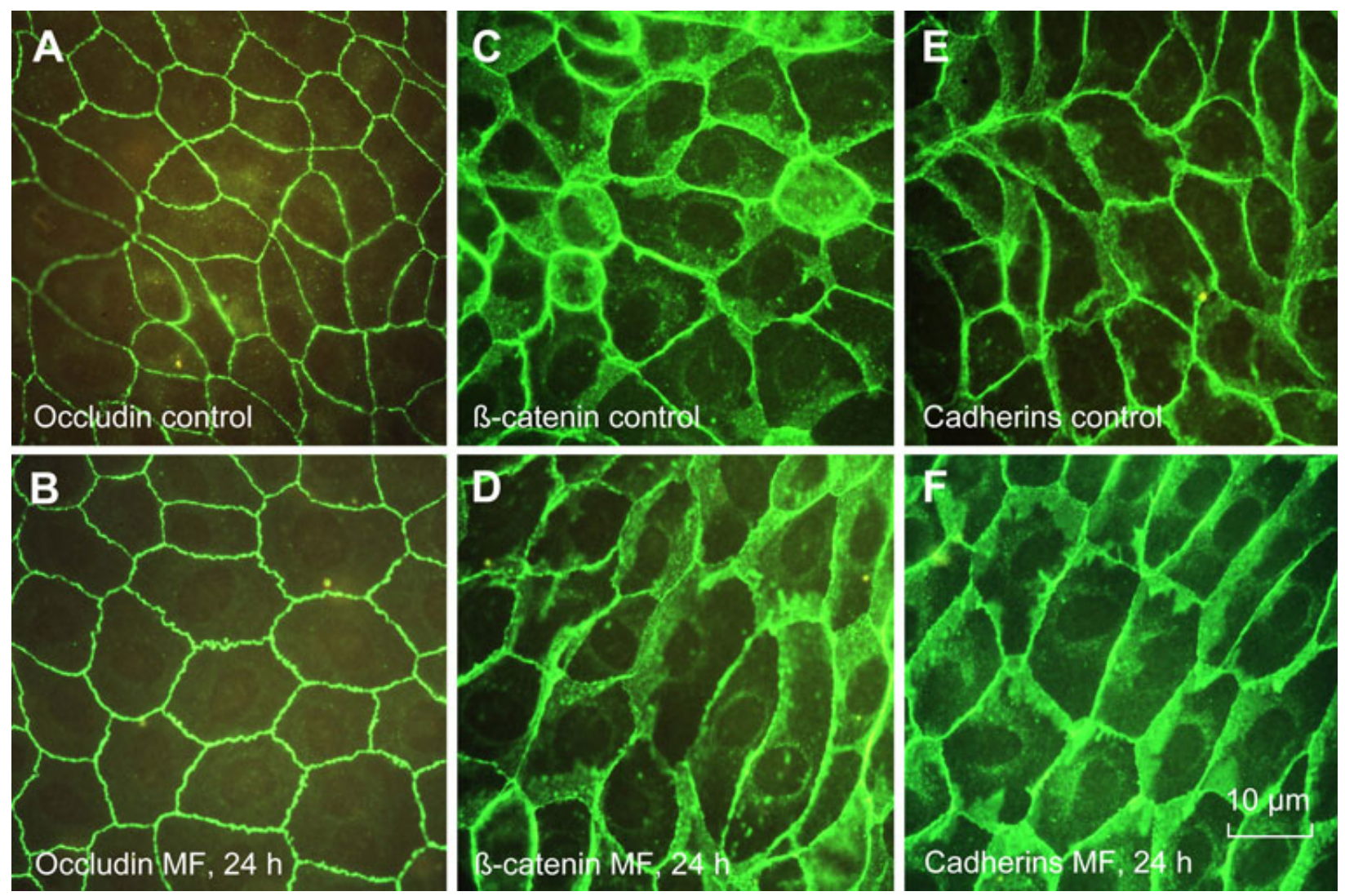

FIGURE 1. Cellular distribution of occludin (A), $\beta$-catenin (C), and cadherins (E) in control and in MF-exposed (50 Hz, $24 \mathrm{~h})(\mathrm{B}, \mathrm{D}$, and E) MDCK cells.

revealed a decrease of the so-called break index indicating the enhanced structural integrity of TJ[34]. It was reported that MF also increase the staining (the amount) intensity of specific proteins at the cell-tocell contact area in keratinocytes[22,24], gonadal cells[26,27], leukocytes[23], and colon tumor model[25].

The fact that both $\mathrm{TJ}$ and $\mathrm{AJ}$ are somehow altered suggests that in epithelial cells the whole junctional complex responds to or affected by the EMF exposure.

$\mathrm{TJ}$ and $\mathrm{AJ}$ are dynamic structures and are regulated by different biologically active extracellular molecules (i.e., hormones, growth factors) and cellular signal transduction systems (i.e., phospholipase C, protein kinases). Second messengers of signal transduction processes, such as $\mathrm{Ca}^{2+}$, cAMP, cGMP, and nitric oxide (NO) seem to play decisive role in this regulation both in coordinating and subordinating relations[2,3,5]. Considering that MF can alter the local calcium concentration[40,41], cAMP[16,42], and NO levels[43,44], their pathogenetic role in the junctional responses is also supposed.

Nevertheless, the functional consequence of such increase in the occludin, cadherin, or $\beta$-catenin staining, as well as the possible stabilization of cell contacts, is still not clear.

Our study shows the total amount, as well as the free cytoplasmic $\beta$-catenin significantly decreased on MF exposure. The altered concentration of free cytoplasmic $\beta$-catenin protein related to Wnt signal changes[2,4,8,10,11].

It is known that the level of $\beta$-catenin pool is depend on the physiological state of cells[11] and it frequently decreases on different chemical and physical toxic effects, i.e., toxic metal exposures[45], ionizing irradiation[32,46,47]. Moreover, the elevated level of cytoplasmic B-catenin is characteristic in different tumor cells $[48,49]$. However, at the current stage of research the behavior of free $\beta$-catenin is not known on MF exposure. 
Our presented new experimental data demonstrate how MF affect TJ and AJ. Based on these results, the possible causative relationship between MF effects and Wnt signaling pathway was first associated.

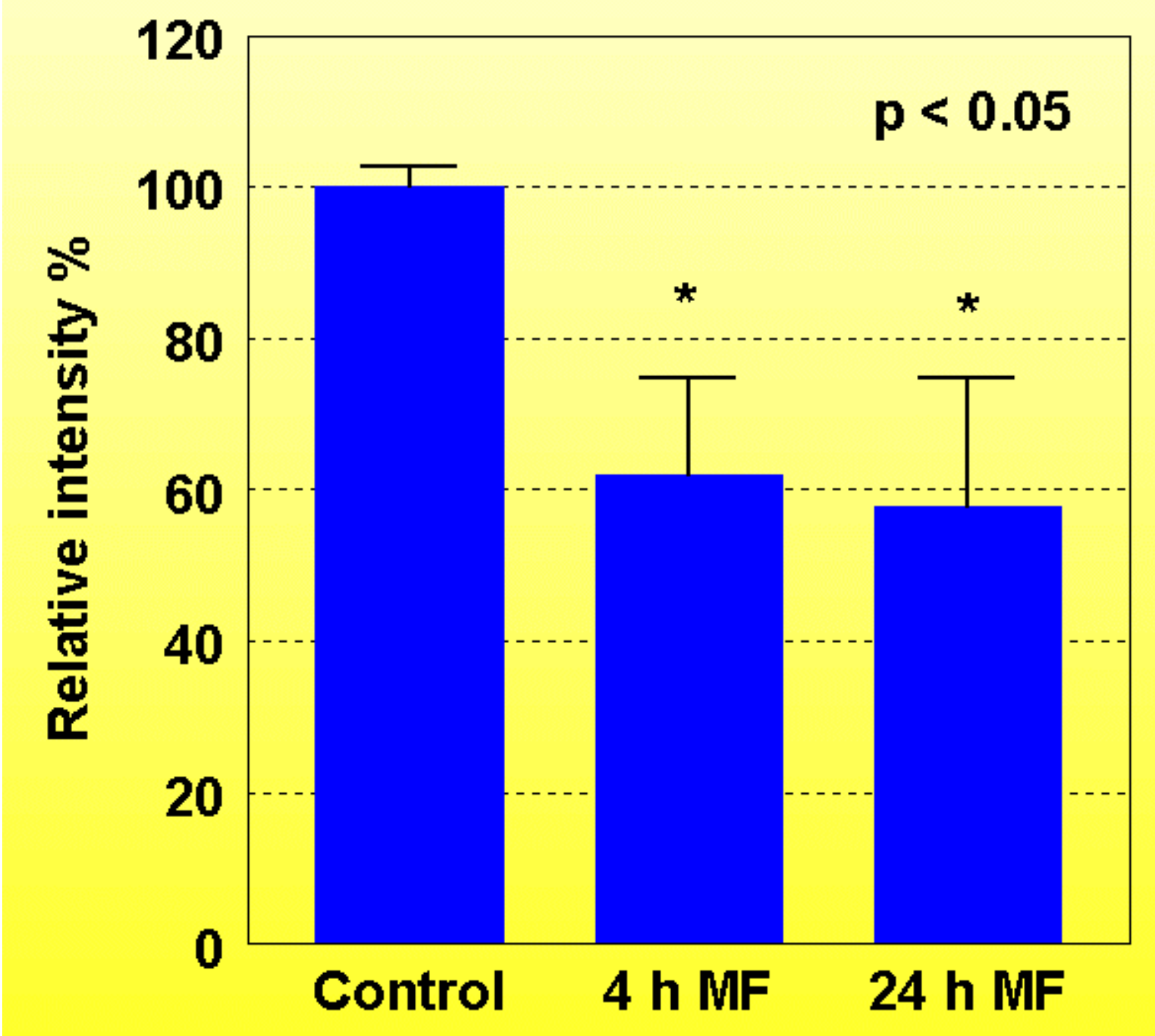

FIGURE 2. The relative amounts of $\beta$-catenin in the control and MF-exposed cells.

\section{ACKNOWLEDGMENT}

Thanks are expressed to Erzsébet Fodor for her excellent technical assistance. This work was supported by the Committee for Health Studies Grant (ETT) of the Hungarian Ministry of Health, Social and Family Affairs under the contract of No. 160/2003, and by research grants from the National Scientific Research Fund (OTKA No. T 034957). 


\section{REFERENCES}

1. Blaschuk, O.W. and Rowlands, T.M. (2002) Plasma membrane components of adherens junctions. Mol. Membr. Biol. 19, 75-80.

2. Gottardi, C.J. and Gumbiner, B.M. (2001) Adhesion signaling: how beta-catenin interacts with its partners. Curr. Biol. 11, R792-R794.

3. Hynes, R.O. (1999) Cell adhesion: old and new questions. Trends Cell. Biol. 9, M33-M37.

4. Takeichi, M.A. (1995) Morphogenetic roles of classic cadherins. Curr. Opin. Cell Biol. 7, 619-627.

5. Schneeberger, E.E. and Lynch. R.D. (2004) The tight junction: a multifunctional complex. Am. J. Physiol. Cell. Physiol. 286, C1213-1228.

6. Jang, Y.J., Kim, H.G., Koo, T.W., and Chung, P.S. (2002) Localization of ZO-1 and E-cadherin in the nasal polyp epithelium. Eur. Arch. Otorhinolaryngol. 259, 465-469.

7. Simcha, I., Kirkpatrick, C., Sadot, E., Shtutman, M., Polevoy, G., Geiger, B., Peifer, M., and Ben-Ze'ev, A. (2001) Cadherin sequences that inhibit beta-catenin signaling: a study in yeast and mammalian cells. Mol. Biol. Cell 12, $1177-1188$

8. Hagen, T., Sethi, J.K., Foxwell, N., and Vidal-Puig, A. (2004) Signalling activity of beta-catenin targeted to different subcellular compartments. Biochem. J. 379(Pt 2), 471-477.

9. Lee, H.Y., Kleber, M., Hari, L., Brault, V., Suter, U., Taketo, M.M., Kemler, R., and Sommer, L. (2004) Instructive role of Wnt/beta-catenin in sensory fate specification in neural crest stem cells. Science 303, 1020-1023.

10. Peifer, M. and Polakis, P. (2000) Wnt signaling in oncogenesis and embryogenesis - a look outside the nucleus. Science 287, 1606-1609.

11. Wodarz, A. and Nusse, R. (1998) Mechanisms of Wnt signaling in development. Annu. Rev. Cell Dev. Biol. 14, 5988.

12. Foster, K.R. (2003) Mechanisms of interaction of extremely low frequency electric fields and biological systems. Radiat. Prot. Dosimetry 106, 301-310.

13. Balzano, Q. and Sheppard, A. (2003) RF nonlinear interactions in living cells. I. Nonequilibrium thermodynamic theory. Bioelectromagnetics 24, 473-482.

14. Rao, R.R. and Kisaalita, W.S. (2004) A single magnetic field exposure system for sequential investigation of real time and downstream cellular responses. Bioelectromagnetics 25, 27-32.

15. Bordiushkov, Iu.N., Goroshinskaia, I.A., Frantsiiants, E.M., Tkacheva, G.N., and Gorlo, E.I. (2000) Neskubina IV. [Structural-functional changes in lymphocyte and erythrocyte membranes after exposure to alternating magnetic field] Vopr. Med. Khim. 46, 72-80.

16. Massot, O., Grimaldi, B., Bailly, J.M., Kochanek, M., Deschamps, F., Lambrozo, J., and Fillion, G. (2000) Magnetic field desensitizes 5-HT(1B) receptor in brain: pharmacological and functional studies. Brain Res. 858, $143-150$.

17. Muehsam, D.J. and Pilla, A.A. (1999) The sensitivity of cells and tissues to exogenous fields: effects of target system initial state. Bioelectrochem. Bioenerg. 48, 35-42.

18. Santoro, N., Lisi, A., and Pozzi, D., Pasquali, E., Serafino, A., and Grimaldi, S. (1997) Effect of extremely low frequency (ELF) magnetic field exposure on morphological and biophysical properties of human lymphoid cell line (Raji). Biochim. Biophys. Acta 1357, 281-290.

19. Fitzsimmons, R.J., Ryaby, J.T., Magee, F.P., and Baylink, D.J. (1995) IGF-II receptor number is increased in TE-85 osteosarcoma cells by combined magnetic fields. J. Bone Miner. Res. 10, 812-819.

20. Zeng, Q.L., Chiang, H., Hu, G.L., Mao, G.G., Fu, Y.T., and Lu D.Q. (2003) ELF magnetic fields induce internalization of gap junction protein connexin 43 in Chinese hamster lung cells. Bioelectromagnetics 24, 134-138.

21. Saunders, M.M., You, J., Zhou, Z., Li. Z., Yellowley, C.E., Kunze, E.L., Jacobs, C.R., and Donahue, H.J. (2003) Fluid flow-induced prostaglandin E2 response of osteoblastic ROS 17/2.8 cells is gap junction-mediated and independent of cytosolic calcium. Bone 32, 350-356.

22. Manni, V., Lisi, A., Pozzi, D., Rieti, S., Serafino, A., Giuliani, L., and Grimaldi, S. (2002) Effects of extremely low frequency $(50 \mathrm{~Hz})$ magnetic field on morphological and biochemical properties of human keratinocytes. Bioelectromagnetics 23, 298-305.

23. Jandova, A., Hurych, J., Nedbalova, M., Trojan, S., Dohnalova, A., Cocek, A., Pokorny, J., and Trkal, V. (1999) Effects of sinusoidal magnetic field on adherence inhibition of leucocytes: preliminary results. Bioelectrochem. Bioenerg. 48, 317-319.

24. Rieti, S., Manni, V., Lisi, A., Giuliani, L., Sacco, D., D'Emilia, E., Cricenti, A., Generosi, R., Luce, M., and Grimaldi, S. (2004) SNOM and AFM microscopy techniques to study the effect of non-ionizing radiation on the morphological and biochemical properties of human keratinocytes cell line (HaCaT). J. Microsc. 213(Pt 1), 20-28.

25. Tuncel, H., Shimamoto, F., Cagatay, P., and Kalkan, M.T. (2002) Variable E-cadherin expression in a MNU-induced colon tumor model in rats which exposed with $50 \mathrm{~Hz}$ frequency sinusoidal magnetic field. Tohoku J. Exp. Med. 198, 245-249.

26. Forgács, Zs., Somosy, Z., Révész, Cs., Jánossy, G., and Thuróczy, G. (2003) Effect of 50 Hz magnetic field exposure on the adherens cell contacts of primary mouse Leydig cells in culture. Acta Biol. Szegediensis 47, 27-30.

27. Forgács, Zs., Somosy, Z., Révész, Cs., Jánossy, G., and Horváth, K. (2004) Alterations of cadherins and $\beta$-catenin staining in $50 \mathrm{~Hz}$ magnetic field exposed primary gonadal cell cultures. Biological Effects of EMFs 3rd International 
Workshop, 4-8 October, 2004, Kos, Greece, in press.

28. D'Andrea, J.A., Chou. C.K., Johnston, S.A., and Adair, E.R. (2003) Microwave effects on the nervous system. Bioelectromagnetics Suppl 6, S107-S147.

29. Tsurita, G., Nagawa, H., Ueno, S., Watanabe, S., and Taki, M. (2000) Biological and morphological effects on the brain after exposure of rats to a $1439 \mathrm{MHz}$ TDMA field. Bioelectromagnetics 21, 364-371.

30. Schirmacher, A., Winters, S., Fischer, S., Goeke, J., Galla, H.J., Kullnick, U., Ringelstein, E.B., and Stogbauer, F. (2000) Electromagnetic fields $(1.8 \mathrm{GHz})$ increase the permeability to sucrose of the blood-brain barrier in vitro. Bioelectromagnetics 21, 338-345.

31. Kovbasnjuk, O.N., Szmulowicz, U., and Spring, K.R. (1998) Regulation of the MDCK cell tight junction. J. Membr. Biol. 161, 93-104.

32. Dublineau, I., Lebrun, F., Grison, S., and Griffiths, N.M. (2004) Functional and structural alterations of epithelial barrier properties of rat ileum following X-irradiation. Can. J. Physiol. Pharmacol. 82, 84-93.

33. Thiagarajah, J.R., Gourmelon, P., Griffiths, N.M., Lebrun, F. Naftalin, R.J., and Pedley, K.C. (2000) Radiation induced cytochrome c release causes loss of rat colonic fluid absorption by damage to crypts and pericryptal myofibroblasts. Gut 47, 675-684.

34. Pálfia, Z., Somosy, Z., and Réz, G. (2000) Tight junctional changes upon microwave and x-ray irradiation. Acta Biol. Hung. 52, 411-416.

35. Somosy, Z., Kovács, J., Siklós, L., and Köteles, G.J. (1993) Morphological and histochemical changes in intercellular junctional complexes in epithelial cells of mouse small intestine upon X-irradiation: changes of ruthenium red permeability and calcium content. Scanning Microsc. 7, 961-971.

36. Porvaznik, M. (1979) Tight junction disruption and recovery after sublethal irradiation. Radiat. Res. 78, $233-250$.

37. Ferruzza, S., Scarino, M.L., Gambling, L., Natella, F., and Sambuy, Y. (2003) Biphasic effect of iron on human intestinal Caco-2 cells: early effect on tight junction permeability with delayed onset of oxidative cytotoxic damage. Cell. Mol. Biol. (Noisy-le-Grand) 49, 89-99.

38. Fiorini, C., Tilloy-Ellul, A., Chevalier, S., Charuel, C., and Pointis, G. (2004) Sertoli cell junctional proteins as early targets for different classes of reproductive toxicants. Reprod. Toxicol. 18, 413-421.

39. Duizer, E., Gilde, A.J., Versantvoort, C.H., and Groten, J.P. (1999) Effects of cadmium chloride on the paracellular barrier function of intestinal epithelial cell lines. Toxicol. Appl. Pharmacol. 155, 117-126.

40. Aldinucci, C., Garcia, J.B., Palmi, M., Sgaragli, G., Benocci, A., Meini, A., Pessina, F., Rossi, C., Bonechi, C., and Pessina, G.P. (2003) The effect of exposure to high flux density static and pulsed magnetic fieldson lymphocyte function. Bioelectromagnetics 24, 373-279.

41. Gartzke, J. and Lange, K. (2002) Cellular target of weak magnetic fields: ionic conduction along actin filaments of microvilli. Am. J. Physiol. Cell. Physiol. 283, C1333-C1346.

42. Schimmelpfeng, J., Stein, J.C., and Dertinger, H. (1995) Action of $50 \mathrm{~Hz}$ magnetic fields on cyclic AMP and intercellular communication in monolayers and spheroids of mammalian cells. Bioelectromagnetic 16, 381-386.

43. Lai, H. and Singh, N.P. (2004) Magnetic-field-induced DNA strand breaks in brain cells of the rat. Environ. Health Perspect. 112, 687-694.

44. Diniz, P., Soejima, K., and Ito, G. (2002) Nitric oxide mediates the effects of pulsed electromagnetic field stimulation on the osteoblast proliferation and differentiation. Nitric Oxide 7, 18-23.

45. Prozialeck, W.C, Lamar, P.C., and Lynch, S.M. (2003) Cadmium alters the localization of N-cadherin, E-cadherin, and beta-catenin in the proximal tubule epithelium. Toxicol. Appl. Pharmacol. 189, 180-195.

46. Somosy, Z., Horváth, K., and Köteles, G.J. (2004) Radiation effects on adherens contacts in cultured Madin-Darby CANINE Kidney (MDCK) cells. Indian J. Radiat. Biol., in press.

47. Park, C.C, Henshall-Powell, R.L., Erickson, A.C., Talhouk, R., Parvin, B., Bissell, M.J., and Barcellos-Hoff, M.H. (2003) Ionizing radiation induces heritable disruption of epithelial cell interactions. Proc. Natl. Acad. Sci. U. S. A. 100, 10728-10733.

48. Horvath, L.G., Henshall, S.M., Kench, J.G., Saunders, D.N., Lee, C.S., Golovsky, D., Brenner, P.C., O'Neill, G.F., Kooner, R., Stricker, P.D., Grygiel, J.J., and Sutherland, R.L. (2004) Membranous expression of secreted frizzledrelated protein 4 predicts for good prognosis in localized prostate cancer and inhibits PC3 cellular proliferation in vitro. Clin. Cancer Res. 10, 615-625.

49. Veeramachaneni, N.K., Kubokura, H., Lin, L., Pippin, J.A., Patterson, G.A., Drebin, J.A., and Battafarano, R.J. (2004) Down-regulation of beta catenin inhibits the growth of esophageal carcinoma cells. J. Thorac. Cardiovasc. Surg. 127, 92-98.

\section{This article should be referenced as follows:}

Somosy, Z., Forgács, Z., Bognár, G., Horváth, K., and Horváth, G. (2004) Alteration of tight and adherens junctions on 50-Hz magnetic field exposure in Madin Darby canine kidney (MDCK) cells. TheScientificWorldJOURNAL 4(S2), 75-82. 

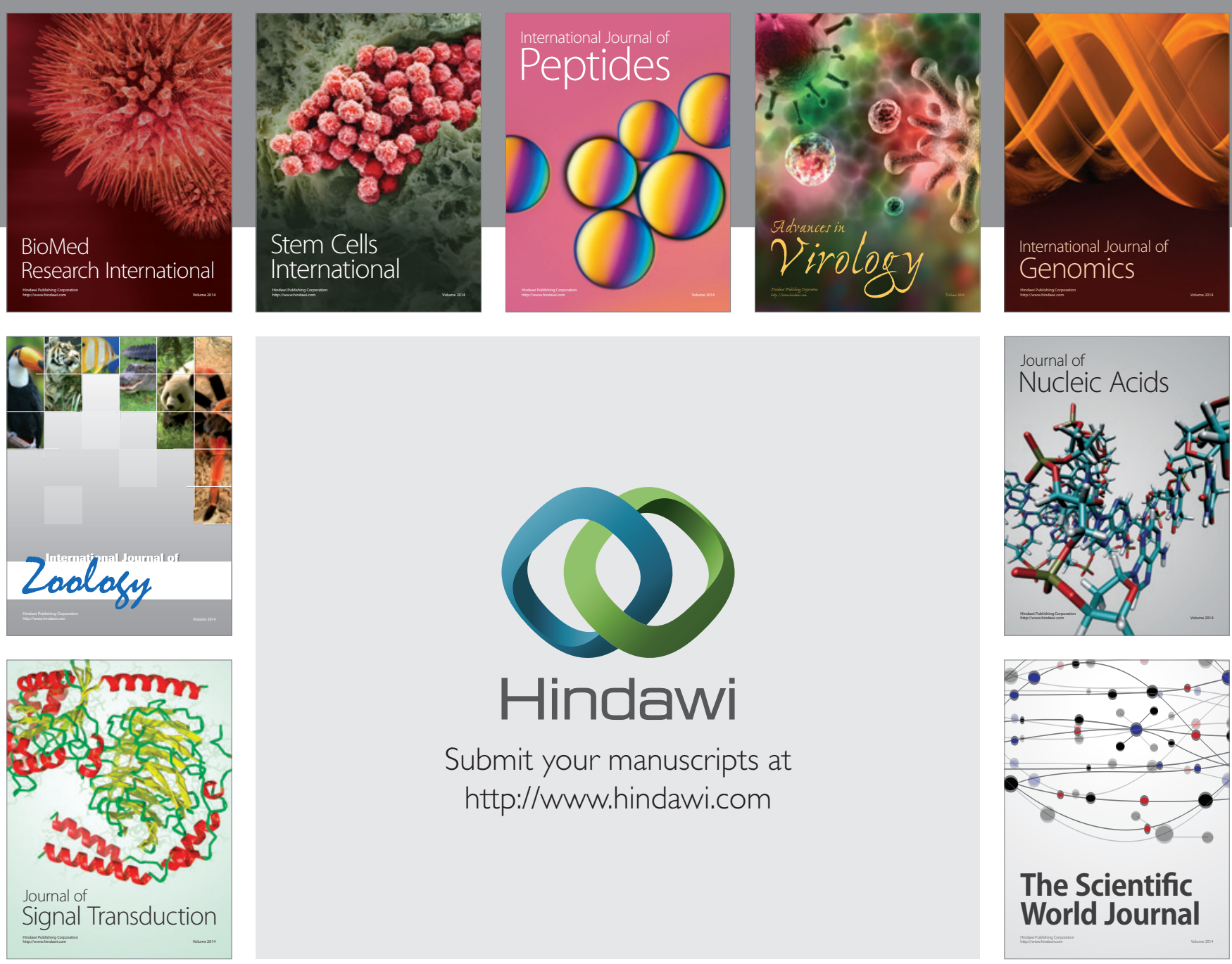

Submit your manuscripts at

http://www.hindawi.com
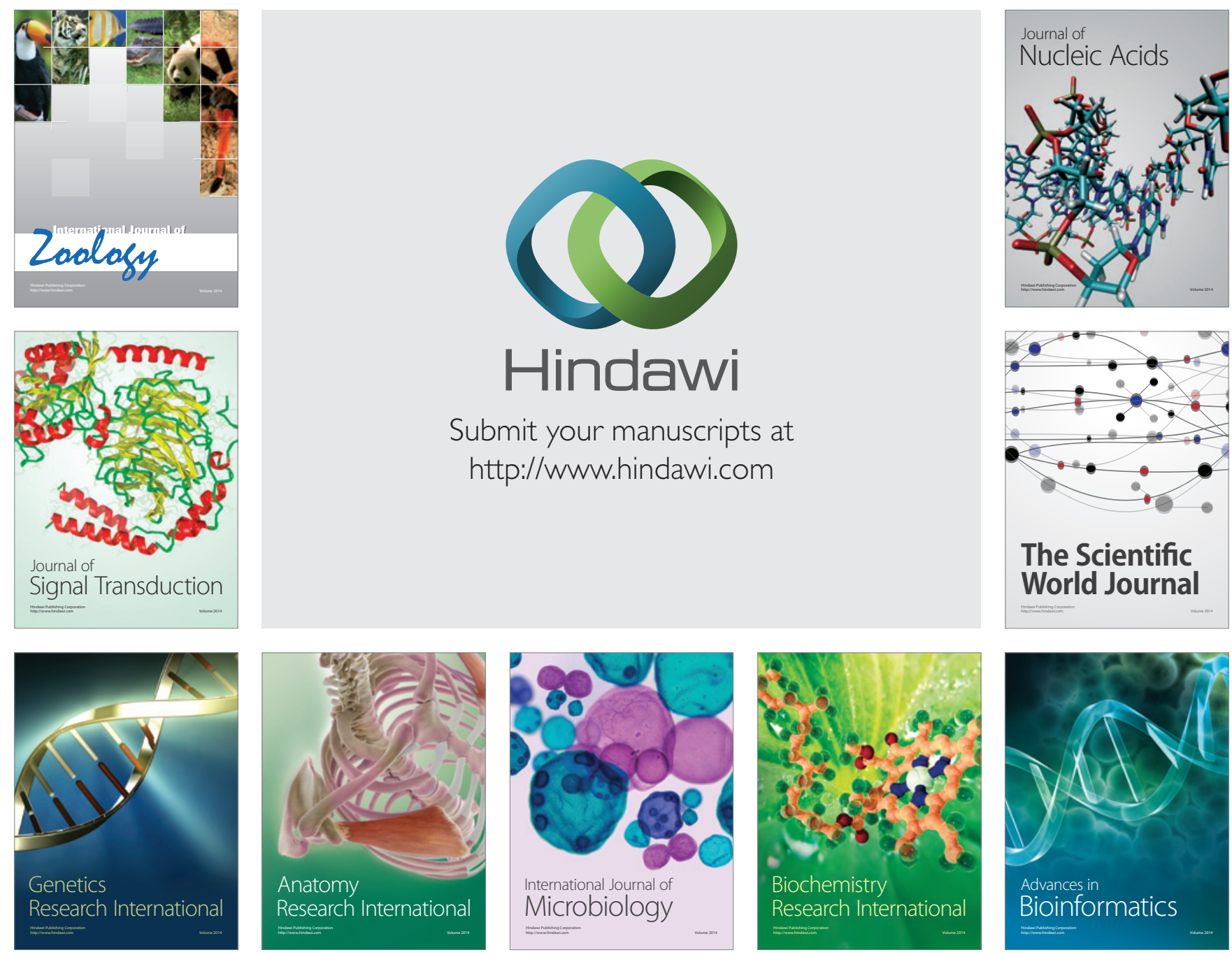

The Scientific World Journal
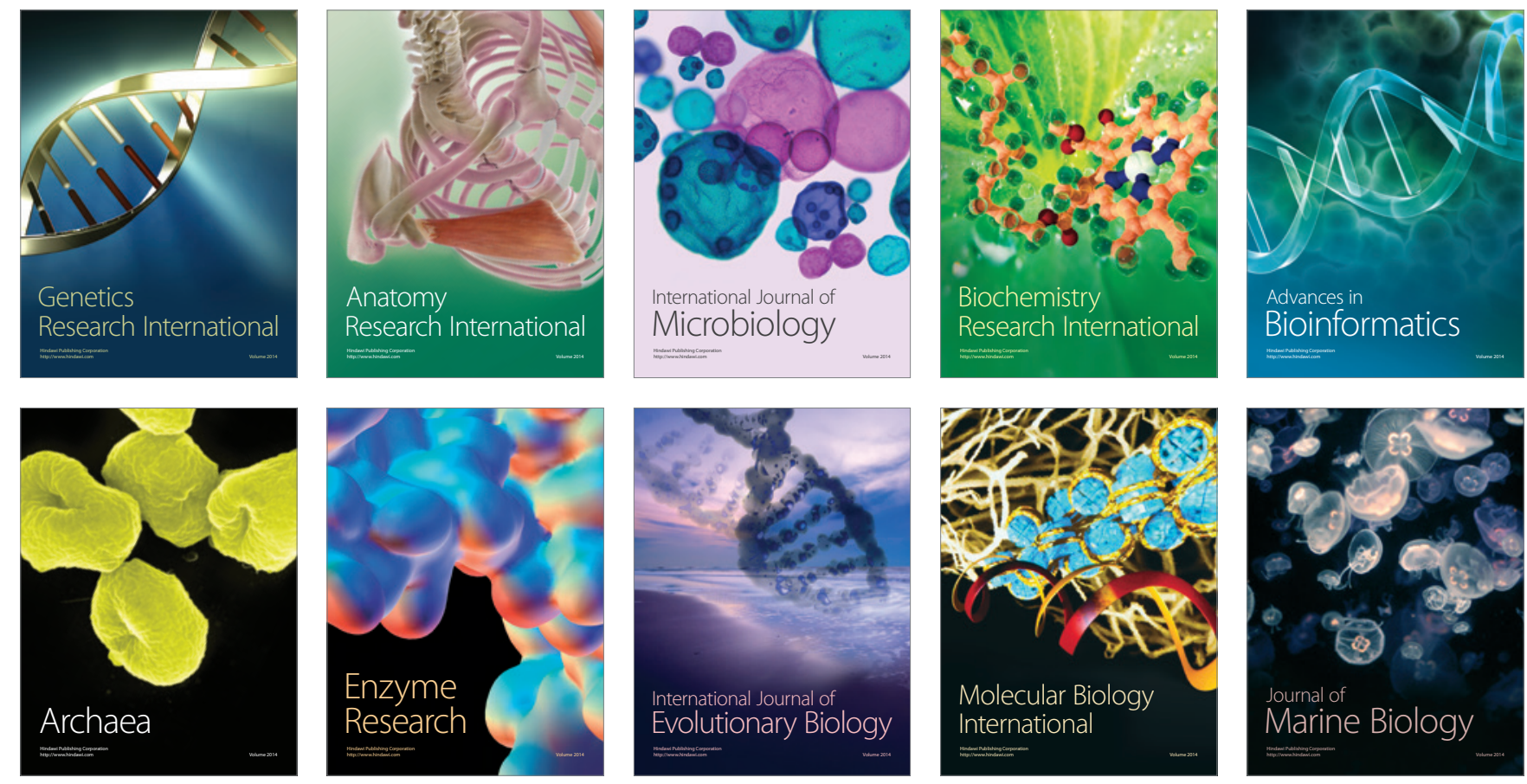